DOI 10.37882/2223-2974.2020.11.29

\title{
ГЕНЕЗИС РАЗВИТИЯ ИНСТИТУТА СЛУЖЕБНОЙ ДИСЦИПЛИНЫ В ПОЛИЦЕЙСКИХ ОРГАНАХ В ДОРЕВОЛЮЦИОННЫЙ ПЕРИОД РОССИЙСКОГО ГОСУДАРСТВА
}

\section{GENESIS OF THE DEVELOPMENT OF THE INSTITUTE OF SERVICE DISCIPLINE IN POLICE BODIES IN THE PRE-REVOLUTIONARY PERIOD OF THE RUSSIAN STATE}

\section{A. Savelyeva}

Summary: The article is devoted to the consideration of the genesis of the development of the institution of service discipline in the domestic police bodies in the pre-revolutionary period of the Russian state. The study of the historical experience of the development of legislation governing the institution of service discipline seems relevant, allowing to identify the origins of the current state of this sphere of regulation. To clarify the legal nature of the service discipline, the author examines the relevant legal relations from the standpoint of historical development. The author traces the evolution of the legal foundations of service discipline in the police bodies in the pre-revolutionary period of the Russian state, shows the complication of the content of normative legal acts governing official legal relations, reveals changes in the conceptual apparatus.

Keywords: history, Russian Empire, police, service discipline, public service, civil service, bureaucracy, police discipline, police service.

\author{
Савельева Анна Андреевна \\ старший лейтенант внутренней службы, адъюнкт, \\ Академия управления МВД России (Москва) \\ MargoSavljeva1982@mail.ru
}

Аннотация: Статья посвящена рассмотрению генезиса развития института служебной дисциплины в отечественных полицейских органах в дореволюционный период Российского государства. Изучение исторического опыта развития законодательства, регламентирующего институт служебной дисциплины, представляется актуальным, позволяющим выявить истоки современного состояние данной сферы регулирования. Автор для уяснения правовой природы служебной дисциплины исследует соответствующие правоотношения с позиций исторического развития. Автор прослеживает эволюцию правовых основ служебной дисциплины в полицейских органах в дореволюционный период Российского государства, показывает усложнение содержания нормативных правовых актов, регламентирующих служебные правоотношения, выявляет изменения в понятийном аппарате.

Ключевые слова: история, Российская империя, полиция, служебная дисциплина, государственная служба, гражданская служба, чиновничество, полицейская дисциплина, полицейская служба.

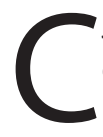
лужба в органах внутренних дел непосредственно связана с обеспечением общественной безопасности, защитой жизни, здоровья, прав и свобод человека и гражданина, охраной общественного порядка. В связи с этим государство устанавливает высокие требования к служебному поведению сотрудников органов внутренних дел. Противодействие нарушениям служебной дисциплины сотрудниками органов внутренних дел, безусловно, важно, так как данные нарушения ведут к подрыву авторитета органов внутренних дел и формируют отрицательное общественное мнение.

Формирование воззрений на институт служебной дисциплины в органах внутренних дел, как одной из разновидностей государственной дисциплины, неразрывно связано с возникновением различных государственных институтов и развитием российской государственности в целом.

Заметим, что регулярные полицейские органы были созданы Петром I (1682-1725 гг.) в начале XVIII века. Как в период становления регулярных полицейских орга- нов, так и в значительно более поздний период, главной особенностью организации полицейской службы было привлечение к ней обывателей и армейских чинов, при этом, вплоть до начала правления императрицы Екатерины II, сохраняется принцип службы как государственной повинности.

Власти столкнулись с рядом трудностей в формировании полицейского аппарата, связанных в первую очередь с тем, что правительство не располагало достаточными средствами для содержания полицейских чиновников и на службу в полицию направлялись военнослужащие из армейских подразделений и подьячие из других учреждений.

Состояние служебной дисциплины на службе в полиции того времени было крайне низким, что, однако, не удивительно, учитывая крайне низкие требования к кандидатам на службу в полиции. Так, в октябре 1726 года, Сенат рассматривал отчет Главной полицейской канцелярии, в котором отмечалось, что в полиции служат освободившиеся с каторги люди, замеченные в кра- 
жах, грабежах, пьянстве и иных нарушениях [1, с. 78]. Как правильно заметил известный полициист XIX в. И.Т. Тарасов, полиция «очень скоро после своего возникновения заявила себя весьма склонной к обидам и взяткам» $[2$, с. 203].

Дисциплинарные отношения на государственной службе в полиции первой половины XVIII века регулировались сообразно военной службе действовавшими воинскими уставами, т.е. в указанный период обособления служебной дисциплины служащих регулярной полиции от воинской дисциплины еще не произошло.

В этой связи стоит отметить то, что несмотря на создание регулярных полицейских органов, отсутствовало четкое название должностей в полиции и определение их субординации (подчиненности) - одного из условий отправления дисциплинарной власти. Только в 1763 г. были утверждены полные штаты полиции в СанктПетербурге и в Москве.

Вместе с тем, с появлением регулярной полицейской службы можно отметить начало формирования статуса полицейского и определения его элементов - совокупности прав, обязанностей, ответственности и правосубъектности. Все полицейские служащие приносили присягу, в которой клялись на верность царю, а также обязались исполнять законы и предписания начальства. После произнесения текста присяги служащие полиции целовали Евангелие и крест[3, с.15]. Таким образом, лица, поступающие на службу, брали на себя ряд обязательств по отношению к государству.

Считаем необходимым отметить, что соблюдение законов и приказаний начальства, добросовестное выполнение полицейским служащим возложенных обязанностей, наряду с прочим и составляет содержание служебной дисциплины на службе в полиции.

Дальнейшее развитие элементы служебной дисциплины служащего полиции получили с подписанием Екатериной II (1762-1796 гг.) 8 апреля 1782 года Устава Благочиния, или полицейского - нормативного правового акта, регламентирующего правовой статус полицейских органов, их систему и основные направления деятельности, а также определившего права и обязанности полицейских служащих.

Необходимо отметить то, что законодательство России ко второй половине XIX в. уже различало гражданскую и военную службу, а полицейская служба уже рассматривалась как составная часть государственной гражданской службы. «Служащий полиции представлял собой лицо, занимающее должность и осуществляющее от имени императора предписанные законом либо иным нормативным актом действия» [4, с. 63].
К середине XIX в органы общей полиции окончательно выделились из системы военных органов, но, тем не менее, к означенному периоду к компетенции полиции было отнесено большое число задач, не связанных с выполнением полицейских функций.

Немаловажным в рамках нашего исследования является то, что в обозначенный период времени были урегулированы в законе и иные существенные стороны государственно-служебных правоотношений, такие как: жалование; пенсия; ограничения; ответственность; поощрения и взыскания.

Государственная служба в полиции окончательно сложилась как институт на рубеже XVIII-XIX вв. в результате слияния военной и гражданской службы, сформировавшейся в XVII в. в результате образования на Руси приказной системы государственного управления. В этот же период был очерчен круг служебных обязанностей чиновников и система их подчиненности.

К середине XIX в. служба в полиции считалась составной частью государственной гражданской службы. В это же время определяется содержание служебной дисциплины, под которой понимается исполнение служащими требований законов, иных нормативных правовых актов, приказаний начальников и добросовестное выполнение возложенных обязанностей в интересах государства.

С развитием института государственной службы происходило и развитие института служебной дисциплины на государственной службе. Говоря же о служебной дисциплине, еще раз остановимся на важнейших ее детерминантах - обязанностях и правах служащих.

Еще в 1902 году известный правовед того времени Н.С. Таганцев отметил то, что государственная служба стала включать в себя два взаимосвязанных вида деятельности: с одной стороны - «исполнение обязанностей в порядке управления, основанное на начале государственной повинности, и исполнение таковых, основанное на начале добровольного вступления в службу, и, в силу сего, добровольного подчинения всем требованиям государственной власти, предъявляемым к такой деятельности в порядке управления»[5, с. 127].

Согласимся с мнением Н.С. Таганцева о том, что именно указанные условия обуславливают возможность выделения особого вида ответственности - ответственности за противоправные деяния по службе.

Сущность государственной службы состоит в закономерном исполнении чиновником возложенных на него обязанностей и добросовестном исполнении служебного долга, состоящем в соблюдении государственного 
интереса и действия по закону [6].

Не исполнение же долга, выражается ли оно в злоупотреблении служебными полномочиями, в неисполнении прямых обязанностей по службе или в недостатке служебного рвения, сделавшим деятельность служащего нецелесообразной или даже вредной, является характерным признаком правонарушения по службе, влекущем ответственность служащего, из чего можно сделать вывод о том, что дисциплина на государственной службе представляет из себя деятельность чиновников по соблюдению требований законов, иных нормативных правовых актов, приказаний начальников и по добросовестному исполнению возложенных на него обязанностей в интересах государства.

Основные обязанности и запреты для государственных служащих, в т.ч. служащих полиции, устанавливались «Уставом о Службе по определению от правительства» (1832 г.)

Говоря о дисциплинарных проступках государственных служащих и наказаниях за их совершение, необходимо сказать, что каждый основной вид службы выработал свою систему проступков и преступлений, совершавшихся исключительно внутри данного рода службы, а также соответствующую систему наказаний.

Так, только к лицам духовного сана применялись такие меры воздействия, как заключение в монастырь на послушание, лишение духовного сана. Исключительно к военнослужащим применялись заключение в крепость, отдача в военно-исправительные роты, разжалование из офицеров в рядовые или матросы.

Служебная дисциплина служащих полиции означала выполнение указанных обязанностей, соблюдение запретов и обязанность неукоснительного соблюдения установленного в полицейских учреждениях порядка управления. За нарушение же порядка выполнения обязанностей по должности и соблюдения установленных запретов, т.е. за проступки и преступления по службе, служащие несли три вида юридической ответственности: уголовную[7], дисциплинарную[8] и гражданскоправовую.

Однако, Устав о службе по определению от правительства фактически не содержал перечня дисциплинарных проступков, и отсылал к другим источникам права, в частности, к Уложению о наказаниях уголовных и исправительных (1845 г.), а затем и к Военно-морскому уставу о наказаниях (1875 г.) [9], содержащих описания конкретных служебных деликтов.

В свете сказанного, возникает необходимость указания на отмеченное А.П. Шергиным обстоятельство, что все более усложняющаяся система государственного управления, а вместе с ним и усложняющееся правовое регулирование деятельности государственных служащих, привели к выделению норм, регулирующих юридическую ответственность должностных лиц, в самостоятельную подотрасль государственной гражданской службы - служебно-деликтное право.

Данное обстоятельство заслуживает упоминания в связи с тем, что по своей сути служебный деликт представляет из себя дисциплинарный проступок, т.е. нарушение установленного порядка выполнения служебных обязанностей служащим. Особенно важной представляется неразрывная связь служебно-правового деликта (дисциплинарного проступка) с установленной законом служебной обязанностью, отмеченная А.Н. Санталовым [10].

В нормативных правовых актах устанавливалась система дисциплинарных взысканий. В частности, в 1831 году Государственный совет вводит такие взыскания на государственной гражданской службе, как выговор и строгий выговор.

Как указал в своем исследовании А.А. Сальников, последний объявлялся чиновникам за несвоевременное выполнение поручений вышестоящих должностных лиц, за необоснованное нарушение сроков предоставления отчетов или срочных донесений. За три строгих или за шесть простых выговоров, полученных гражданскими служащими в течение одного года, при совершении нового проступка по службе они могли быть преданы суду, который, в зависимости от степени тяжести упущений и совершенных проступков, мог принять решение о вычете из служебного стажа служащего полгода или год[1 1, с.82].

При этом, все в большей степени проявляются отличия служебной дисциплины на государственной гражданской службе, к которой относилась и служба в полиции, от воинской дисциплины, что также проявляется и в особенностях применяемой на службе в полиции дисциплинарной практики.

С развитием государственной полицейской службы, развивалась ее нормативно-правовая база, а вместе с ней совершенствовался механизм правового регулирования прохождения государственной полицейской службы, включая вопросы правового регулирования дисциплинарных отношений на службе в полиции, но их поступательное развитие было прервано наступившей чередой революций и начавшимся после них строительством государства нового типа - советского социалистического государства[12, с. 1101].

Таким образом, исследование генезиса института служебной дисциплины позволяет сделать вывод о том, 
что источники его правового регулирования характеризуются последовательным развитием и преемственностью нормативных предписаний с одновременным совершенствованием понятийного аппарата, процедурных вопросов, уточнением субъектного состава, видов дисциплинарных взысканий.
Рассмотрение института служебной дисциплины в органах внутренних дел России в историческом контексте позволяет более глубоко понять природу данного правового института, а также учесть накопленный опыт при совершенствовании его правового регулирования в современных условиях.

\section{ЛИТЕРАТУРА}

1. Лысенко В.В. Полиция дореволюционной России и противоправные проявления в области общественной нравственности: Теорет. и ист.-правовой анализ: дисс. ... докт. юрид. наук: 12.00.01. -СПб., 1998. - 396 с.

2. Тарасов И.Т. История русской полиции и отношения к юстиции // Юридический вестник: Февраль. Издание Московского Юридического Общества. - М.: Тип. А.И. Мамонтова и Ко, 1884, № 2. - С. 177-212.

3. Сизиков М.И. История полиции России (1718-1917): Становление и развитие общ. регуляр. полиции в России XVIII В. / М. И. Сизиков. - М.: АПО, 1992. - 66 с.

4. Сальников А.А. Правовой статус сотрудника полиции во второй половине XIX - начале XX века: дисс. ... канд. юрид. наук: 12.00.01. - Нижний Новгород, 2010. -234 c.

5. Черняев В.Ю. 0 Таганцеве Н.С. и его дневнике // Звезда. 1998. №9. С. 126-129.

6. Капустина И.Ю. Административно-правовые средства обеспечения законности и дисциплины службы в органах внутренних дел: автореферат дис. ... кандидата юридических наук: 12.00.14 / Капустина Ирина Юрьевна; Санкт-Петербург, 2009.- 27 с.

7. Тимофеевский В.И. Систематический сборник решений Правительствующего сената, по вопросам об ответственности должностных лиц административного ведомства за преступления должности. (1868-1896 г.) / Сост.: чл. Консультации при М-веюст. учрежденной, исп. обяз. товарища обер-прокурора 1 Деп. Правительствующего сената В.И. Тимофеевский и бывш. обер-секр. того же Департамента С.П. Кузнецов. -СПб.: тип. Правительствующего сената, 1896. -930 c.

8. Лазаревский Н.И. Ответственность за убытки, причиненные должностными лицами: Догмат. исслед. -СПб.: тип. Спб. акц. общ. печатного и писчебум. дела в России «Слово», 1905. - 712 с.

9. Широков Н.Н. Устав о службе по определению от правительства . . . / Сост. б. ст. ревизор С.-Петерб. контр. палаты Н.Н. Широков. - Неофиц. изд. -СПб.: тип. А0 «Слово», 1910. -362 с.

10. Россия. Законы и постановления. Уложение о наказаниях уголовных и исправительных. -СПб.: Тип. 2 отд-ния собств. е. и. В. канцелярии, 1845. - 898 с.

11. Маюров Н.П. Дисциплинарные правоотношения в советской милиции (1917-1991 гг.): Историко-правовое исследование: дисс. ... докт. юрид. наук: 12.00.01. -СПб., 2005. -495 C.

12. Беженцев А.А., Шевченко И.А. Соблюдение служебной дисциплины сотрудниками органов внутренних дел как условие повышения безопасности их служебной деятельности. // В сборнике: Российская полиция: три века служения Отечеству Материалы юбилейной международной научной конференции, посвященной 300-летию российской полиции. 2018. С. 1099-1104.

(с) Савельева Анна Андреевна (MargoSavljeva1982@mail.ru). 